\title{
Study of antiapoptotic effect of a protein isolated from Megalopyge albicolis (Lepidoptera: Megalopygidae) hemolymph
}

\author{
Marina Katia Ferreira Mazzoni", Nathalia Delazeri de Carvalho, Henrique Krambeck Rofatto, \\ Roberto Enrique Pinto Moraes, Ronaldo Zucatelli Mendonça \\ From 5th Congress of the Brazilian Biotechnology Society (SBBIOTEC) \\ Florianópolis, Brazil. 10-14 November 2013
}

Apoptosis has a central role in many cellular processes and development of some diseases like cancer and Alzheimer's. Molecules that interfere in the apoptotic process may be used in the biotechnology industry, the control of cell death occurring in high density cultures performed in bioreactors is an important factor in production processes. Has been shown that hemolymph of the Lonomia obliqua (Lepdoptera:Saturniidade) is capable of inhibiting cell death in different models [1-3]. The objective of this study, is to identify the potential anti-apoptotic of a protein isolated from hemolymph of larvae of Megalopyge albicolis (Lepidoptera: Megalopygidae). Methods: The hemolymph was collected and the citotoxicity was evaluated in culture (up to 5\%). The anti-apoptotic protein responsible for this activity was isolated and purified by gel filtration chromatography using a gel filtration column system (Superdex 75). The fractions obtained were tested for anti-apoptotic activity in VERO and Sf-9 cells. Apoptosis was induced with 25 to $250 \mu \mathrm{M}$ of Tert-butyl or $800 \mathrm{ng} / \mathrm{mL}$ of Actinomicin D in cells treated and not treated with hemolymph. After 18 hours, the cells were stained with acridine orange and ethidium bromide and observed in confocal microscope. To study the cytoskeleton, the cells were incubated with faloidina-FITC after 4 hours of apoptosis induction. Results and Conclusions: Cytotoxicity of Megalopyge albicolis hemolymph was evaluated and no adverse effect was observed. This protein was capable to protect cells against death induced and was able to avoid the lost of cytoskeleton structure. The hemolymph of $M$. albicolis contain components able to inhibit death by apoptosis induced by chemical agents. Was observed that this component can act in cytoskeleton structure, increasing the cell viability acting to maintain the physiological and functional conditions of the cells. The activities exhibited by this protein are of great interest for the development of products to be employed in cell and tissue culture procedures, where the increase in cell viability is important to maintain the physiological and functional conditions of the cells.

\section{Acknowledgements}

FAPESP 10/52434-6.

Published: 1 October 2014

\section{References}

1. Vieira HLA, Pereira ACP, Peixoto CC, Moraes RHP, Alves PM, Mendonça RZ: Improvement of recombinant protein production by an anti-apoptotic protein from hemolymph of Lonomia obliqua. Cytotechnology 2010, 62:547-555.

2. Maranga L, Mendonca RZ, Bengala A, Peixoto CC, Moraes RH, Pereira CA, Carrondo MJ: Enhancement of Sf-9 cell growth and longevity through supplementation of culture medium with hemolymph. Biotechnol Prog 2003, 19:58-63.

3. Souza AP, Peixoto CC, Maranga L, Carvalhal AV, Moraes RH, Mendonca RM, Pereira CA, Carrondo MJ, Mendonca RZ: Purification and characterization of an anti-apoptotic protein isolated from Lonomia obliqua hemolymph. Biotechnol Prog 2005, 21:99-105.

\section{doi:10.1186/1753-6561-8-S4-P148}

Cite this article as: Ferreira Mazzoni et al: Study of antiapoptotic effect of a protein isolated from Megalopyge albicolis (Lepidoptera: Megalopygidae) hemolymph. BMC Proceedings 2014 8(Suppl 4):P148. 